\title{
The Effect of Confidence through Emotional Branding Honda Motorcycle Customer Satisfaction:A Case Study of Maumere, Indonesia
}

\author{
Nunsio Handrian Meylano', Harianto Respati ${ }^{2}$ \& Achmad Firdiansjah ${ }^{3}$ \\ ${ }^{1}$ Master of Management Program, University of Merdeka Malang, Indonesia \\ ${ }^{2.3}$ Faculty of Economics, University of Merdeka Malang, Indonesia
}

\begin{abstract}
The purpose of this study is to describe the emotional branding, satisfaction and trust of Honda motorcycle customers, analyze the influence of emotional branding on Honda motorcycle customer satisfaction, analyze the influence of emotional branding on customer confidence in Honda motorcycles, analyze the effect of customer satisfaction on customer confidence in Honda motorcycles, and analyze emotional branding on trust through customer satisfaction Honda motorcycle. The population of this research is all Honda motorcycle users in Maumere, based on data from the Central Bureau of Statistics East Nusa Tenggara province, amounting to 39.517 people. The Number of samples this study of 100 users of Honda brand motorcycles. The sampling technique is simple random sampling. The data analysis technique is the description and path analysis. Research shows that Emotional branding effect on confidence. Emotional branding affects customer satisfaction and customer satisfaction affects trust. An important finding of this study is Emotional branding is an important part of Honda Motorcycles and able to create a sense of trust for users of Honda motorcycles, especially the reliability of the product.
\end{abstract}

Keywords: Emotional Branding, Trust, Customer Satisfaction.

\section{INTRODUCTION}

Motorcycles very important role in supporting a variety of community activities. Therefore, it is not surprising that people take a lot of consideration to get a motorbike with many advantages. Honda motorcycle is a motor that comes with many advantages. In addition to fuel economy and has a range of spare parts, various motors Honda present to help meet the needs of every strata of society.

Consumer behavior is very influenced by emotional branding. According to Gobe, emotional branding is a channel where people unconsciously relate to the company and the company's products in an emotionally admirable method [1]. Emotional as a driver of customer satisfaction. Customer satisfaction is an attitude based on a person's past experience where the experience supports the development of trust to keep buying in the company. Customer satisfaction as a conscious evaluation involves whether the product is relatively good or bad or whether the product is suitable or not suitable for the intended use [2]. Trust is a foundation of a business. Establish a customer's trust is one way to create and maintain customer [3].

Emotional factors that are owned by consumers was also instrumental in creating satisfaction. The emotional effect can affect attitudes towards Honda motorcycles through advertisements that are displayed. Obtained as a result of a display advertisement that responds to consumers in its rapid appraisal process both positively and negatively regarding Honda motorcycle products.

Research results Oktaviani, Setiadi et al., Pradana and Suryoko, Istiqo and Poernomo, and Fatir et al. proved that found that emotional branding effect on customer satisfaction $[4,5,6,7,8]$. Customers who are satisfied with Honda motorcycles will believe that the useful product used in everyday activities. Customer satisfaction is one important factor that must be considered by the company because the customer is the reason why a company exists and without the company's customers can not maintain the survival of the company. If the benefits provided by Honda motorcycles exceed consumer expectations, consumers will feel satisfied, otherwise if less than expectations, consumers will be disappointed. With a high level of satisfaction will further increase consumer confidence. Older customers can be retained and increasingly make repeated purchases. 


\section{THEORITICAL REVIEW}

\subsection{Emotional Branding}

According to Irawan Emotional is an important factor affecting customer satisfaction [9]. There are many emotional factors when consumers make purchases where when you first see a product, the design according to their likes, colored according to favorite color, so emotionally consumers will soon make a response that consumers want to have the product. Meanwhile, according to Krishnan and Olshavsky, emotions have a double role in the customer satisfaction [10]. Is emotions that arise in the perception of the performance and emotions that arise during the process of evaluation of performance. Emotional branding is a situation that aroused from the organism, includes realized changes, the nature and depth of emotional branding perilaku.Indikator changes as follows: relationship.

According to Gobe, emotional branding is a channel where people unconsciously connect with the company and with products from the company in an emotionally admirable method. Emotional as a driver of customer satisfaction [1]. Anoragasuggests emotional a condition that can affect one's actions to make a plan that pleases [11]. Emotional action is also a personal urge someone to do an activity. With the encouragement of emotion then people can act as he wishes.

\subsection{Customer satisfaction}

Kotler defines satisfaction as one's feelings of pleasure or disappointment arising after comparing between perceptions or impressions on the performance of a product and its expectations [12]. The level of satisfaction is a function of the difference between the performance he feels and expectations. Anwar et al. (2017) describes the perception of satisfaction is part of the pleasure felt by the individual. Customers can understand one level of general satisfaction, namely if the performance is below expectations, then consumers will be disappointed, performance is as expected, then consumers will be satisfied, then performance exceeds expectations, then consumers will be very satisfied. Customersatisfaction is the attitude of consumers after using a Honda motorcycle. The indicators used are: suitability of expectations, ease of obtaining and willingness to recommend.

According Jasfar customer satisfaction with a service are: Comparison between the perception of the service received with expectations before using the service [14]. If expectations are exceeded, it means that the service has provided an extraordinary quality and will also lead to very high satisfaction. Conversely, if expectations are not achieved, it means the quality of the service does not meet what is desired or the company fails to serve consumers. If the expectation is the same as what is obtained, it means that the consumer is satisfied.

\subsection{Trust}

Sam and Tahir argue that trust is a characteristic that is determined by factors of uncertainty, instability, and dependence [15]. Trust is understood as the dimension of a relationship that determines a behavior in which a party feels able to trust the integrity of the promises offered by the other party. Trust in this case is a feeling to be able to trust the other party for all the promises that have been given.

Morgan and Hunt explain that the relationship between companies and consumers are determined by the confidence and commitment [16]. Soegoto states that trust is related to emotional branding, which is the ability of a person to entrust a company or a brand to perform a function, so that it can be predicted that trust will have a positive relationship with repurchase interest and loyalty [17]. Trust is the confidence of consumers to use the product. The indicators used in trust are as follows: honesty, excellence and competence.

\section{METHOD}

\subsection{Population and Sampling Techniques}

The population in this study were all Honda motorcycle users in Maumere based CPM East Nusa Tenggara province, amounting to 39.517 peoples. Sample part of the population. The formula used in the determination of the sample used is Yamane. Based the calculation formula, the number of samples in this study were 100 orang. Technique sampling using simple random sampling is said to be simple because simple or sampling conducted random member of the population, regardless of the strata contained in the population.

\subsection{Data analysis technique}

A method of analyzing the data in thisstudywas done byusingpathanalysis, With a model of the following equation:

$\mathrm{Y} 1=\mathrm{b} 1 \mathrm{X} 1+\mathrm{e} 1$

$\mathrm{Y} 2=\mathrm{b} 2 \mathrm{X} 1+\mathrm{e} 2$

$\mathrm{Y} 2=\mathrm{b} 3 \mathrm{Y} 1+\mathrm{e} 2$ 


\section{ANALYSIS OF RESULTS}

\subsection{Structural Equation Model}

Based on the results of the path analysis, the model of the path in the path analysis presented Figure 1 following.

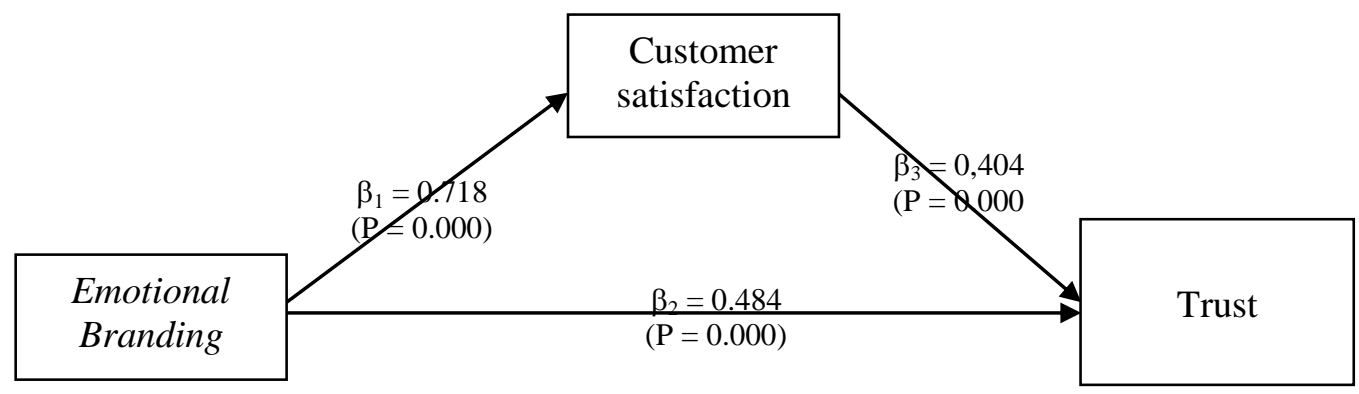

Sources: Primary data is processed, 2020.

Picture 1 The Result Path Analysis

The results of path analysis study variables are presented in Table 1 below.

Table 1 Variable Path Analysis Research

\begin{tabular}{|l|c|c|c|c|}
\hline \multicolumn{1}{|c|}{ Variables } & Direct Effect & P-value & Indirect Effect & Total Effect \\
\hline Emotional branding $\rightarrow$ Satisfaction & 0.718 & 0.000 & - & - \\
\hline Emotional branding $\rightarrow$ Trust & 0.484 & 0.000 & - & - \\
\hline Customer satisfaction $\rightarrow$ Trust \\
\hline $\begin{array}{l}\text { Emotional branding } \rightarrow \quad 0.404 \\
\text { satisfaction } \rightarrow \text { Trust }\end{array}$ & 0.484 & 0.000 & - & - \\
\hline
\end{tabular}

Sources: Primary data is processed, 2020.

\subsection{Hypothesis Test Results}

a. Hypothesis $\mathrm{H} 1$

Based on Table 1 obtained value emotional branding beta coefficient of 0.718 and $t$ value of 10.210 and a $p$-value of 0.000 smaller of $\mathrm{p}=0.05(\alpha=5 \%)$, which means that the emotional branding significant effect on customer satisfaction. Thus the hypothesis The first states that emotional branding significant effect on customer satisfaction was statistically tested.

b. Hypothesis $\mathrm{H} 2$

Based on Table 1 obtained value emotional branding beta coefficient of 0.484 and $t$ value of 5.840 and $p$-value of 0.000 smaller of $\mathrm{p}=0.05(\alpha=5 \%)$, which means that emotional branding significant effect on confidence. Thus the hypothesis The second states that emotional branding take effect significantly to confidence statistically proven.

c. Hypothesis $\mathrm{H} 3$

Based on Table 1 obtained value customer satisfaction beta coefficient of 0.404 and t value of 4.871 and $p$-value of 0.000 smaller of $p=0.05(\alpha=5 \%)$, which means that the customer satisfaction significant effect on confidence. Thus the hypothesis The third states that affects customer satisfaction significantly to confidence statistically proven.

d. Hypothesis $\mathrm{H} 4$

Based on Table 1, the results of the analysis show that satisfaction is an intervening variable that can mediate emotional branding variables on trust, because the values of $b 1, b 2, b 3 \neq 0$, then Ha is accepted. Thus the fourth hypothesis stating emotional branding has a significant effect on trust through customer satisfaction is statistically tested.

\section{DISCUSSION OF RESULTS}

\subsection{Description Emotional Branding, Customer Satisfaction and Trust}

Emotional brandingformed by relationship, sensory experience, and imagination. The main thing that encourages emotional branding is reflected in the imagination of quality Honda motorcycle. Honda Motor is known for the quality of the machine, it shows that Honda motor company is able to maintain its quality. Quality is the key to the motorcycle so widely known. As the opinion of Gobe which states that emotional branding is a channel where people unconsciously connect with the company and with products from the company in an emotionally admirable method [1]. 
Customer satisfaction is formed by conformity hope, ease of obtain and willingness to recommend. The main thing that can create customer satisfaction is reflected in the willingness to recommend the respondents are willing to advise relatives to use a Honda motorcycle. Customer satisfaction can be created if the desires and expectations can be realized motorcycle company Honda. As opinion Tjiptono which states that customer satisfaction is customer satisfaction is a full evaluation where the alternative chosen at least gives the same outcome or exceeds customer expectations, while dissatisfaction arises when the results do not meet expectations [18].

Trust established by the honesty, excellence and competence. The main thing that can enhance the excellence trust is reflected driving a Honda motorcycle fun. Trust in a Honda motorcycle can provide a sense of prestige and pride to its customers so that it becomes the first and diutama into consideration the customer to always use the bike Honda. As Mayer et al. which states that customer trust is one's willingness to be sensitive to the actions of others based on the expectation that others will take certain actions on people who trust them, without depending on their ability to supervise and control them [19].

\subsection{Emotional Branding and Customer Satisfaction}

Emotional brandingeffect on confidence, which means that the better emotional branding is no trend of increasing customer satisfaction. Indicators of emotional branding which gives the largest contribution to peningaktan imagination customer satisfaction is reflected in the quality of Honda motorcycles can increase customer satisfaction so that customers are willing to recommend to relatives to use Honda motorcycles.

In principle, the company's goal is to create satisfaction with customers. The higher the level of customer satisfaction, it will bring greater profits for the company, because customers can repurchase the company's products. Owever, if the level of satisfaction felt by the customer is small, then there is a possibility that the customer will move to the company's competing products. The results of this study are consistent with Oktaviani, Setiadi et al., Pradana and Suryoko, Istiqo and Poernomo, Fatir et al. which states that emotional branding affects customer satisfaction $[4,5,6,7,8]$.

\subsection{Emotional Branding and Faith}

Emotional branding effect on trust, meaning that both emotional branding created companies can create trustcustomer. Honda motorcycle customers trust could be formed when marketers succeedcreate and maintain a positive emotional connection with consumers. High customer confidence is a reflection of the credibility of a Honda motorcycle company by offering products or services that are reliable and have emotional value among the customers with the company. The results of this study are consistent with Wijarnarka et al. who examined Eiger Adventure products in Semarang and proved emotional branding has an effect on trust [20].

\subsection{Customer Satisfaction and Trust}

Customer satisfaction influences trust, which means that the higher level of customer satisfaction can increase trust. An indicator of customer satisfaction that gives the biggest contribution to increasing trust is a willingness to recommend reflected by customers willing to suggest relatives to use Honda motorcycles. Trust is an effect that a rises from the suitability of expectations, the ease of obtaining and the willingness to recommend. The results are consistent with Norhermaya and Susanto and Leninkumar which states that affect the trust of customer satisfaction $[3,21]$.

\subsection{Role of Customer Satisfaction}

Customer satisfaction mediates the influence of emotional branding of the trust. This suggests that emotional branding can boost confidence if supported customers are satisfied with after using Honda motorcycles. Emotional branding is reflected in the employees are friendly to consumers, Honda motorcycles have attractive colors and quality can improve customer satisfaction is reflected in the motorcycle Honda has been reliable in the public, customers are satisfied because the motorcycle shop Honda scattered throughout Indonesia and willing to advise relatives to Honda motorcycle use can create customer confidence. Customer satisfaction as a guarantee of success of the company in the future. Customers are satisfied when the service performance approaching or exceeding the desired service level, customers are likely to make repeat purchases, then spread positive word of mount.

\section{CONCLUSION AND SUGGESTION}

\subsection{Conclusion}

Results Descriptive statistics show that Emotional branding is formed by relationship, sensory experience, and imagination. The main thing that encourages emotional branding is reflected in the imagination of quality Honda motorcycle. Customer satisfaction is formed by the conformity of hope, the ease in obtaining and willingness to recommend. The main thing that creates customer satisfaction is reflected in the willingness to recommend the respondents are willing to advise relatives to use a Honda motorcycle. Trust established by the honesty, excellence and competence. The main thing that could improve the confidence is reflected advantages of driving a Honda motorcycle fun. 
Emotional branding effect on confidence, which means that the better emotional branding on Honda motorcycles can increase user confidence Honda motorcycles.Emotional brandingeffect on customer satisfaction, which means that the better emotional branding can enhance customer satisfaction Honda motorcycle users. Customer satisfaction effect on confidence, which means that the higher the level of customer satisfaction can increase user confidence Honda motorcycles. Emotional branding effect on trust through customer satisfaction, which means that trust can be enhanced if the emotional branding and can satisfy users Honda motorcycles.

\subsection{Suggestion}

The company that manufactures motorcycles Honda brand motorcycles (PT Astra Honda Motor / AHM) is recommended to maintain the quality honda motorcycle that consumers do not switch to another brand. To improve customer satisfaction the company should continue to provide spare parts in order to enable customers to meet the needs of spare parts for Honda motorcycles.

For future researchers, according to the statement Respati which states that organizations / companies need to utilize the resources optimally to produce reliable products to generate customer satisfaction, it is suggested that future researchers in order to add another variable that is more precise in predicting trust the brand bicycle Honda, which adds variable product reliability as independent variables in the structural equation model built in this study [2].

\section{Notes}

Nunsio Handrian Meylano is a Master of Management at University of Merdeka Malang, Indonesia, and University of Nusa Nipa Maumere, Indonesia.

Harianto Respati is a Lecturer in the Department of Management at the Faculty of Economics, University of Merdeka Malang, Indonesia.

Achmad Firdiansjah is Lecturer in the Department of Management at the Faculty of Economics, University of Merdeka Malang, Indonesia..

\section{REFERENCES}

1. Gobe, M. 2005. Emotional Branding: Paradigma Baru Untuk Menghubungkan Merek Dengan Pelanggan. Jakarta: PT. Erlangga.

2. Respati, Harianto. 2010. Total Quality Manajemen dan Daya Saing Perusahaan sebagai Antesenden Kepuasan Pelanggan menghadapi Perdagangan Bebas CAFTA 2010. Jurnal Iqtishoduna. Vol.6.No.1

3. Norhermaya, Yashinta Asteria dan Harry Soesanto. 2016. Analisis Pengaruh Kepuasan Pelanggan Terhadap Kepercayaan dan Loyalitas Pelanggan Untuk Meningkatkan Minat Beli Ulang (Studi Pada Online Store Lazada.co.id). Diponegoro Journal of Management. Volume 5 No. 3: 1-13.

4. Oktaviani, Winda. 2014. Pengaruh Kualitas Layanan, Emosional Pelanggan, dan Kemudahan Terhadap Loyalitas Melalui Kepuasan Pelanggan. Jurnal Ilmu Manajemen. Volume 2 Nomor 1: 140-152.

5. Setiadi, Gunung, Handoyo Djoko dan Ngatno. 2015.Pengaruh Emotional Branding, Nilai Pelanggan dan Citra Merek Terhadap Loyalitas Pelanggan Melalui Kepuasan Pelanggan J.Co Java Mall Semarang. Jurnal Administrasi Bisnis. Universiats Diponegoro. Semarang.

6. Pradana, Rizki Ichwan dan Sri Suryoko. 2015. Pengaruh Kualitas Pelayanan dan Emotional Branding Terhadap Kepuasan Konsumen (Studi Kasus Pasien Rawat Inap Rumah Sakit Umum Permata). Jurnal Adminsitrasi Bisnis. Universitas Diponegoro Semarang.

7. Istiqo, Catur M dan Eddy Poernomo. 2017. Pengaruh Kualitas Pelayanan, Harga, Dan Faktor Emosional Terhadap Kepuasan Pelanggan Pada Hotel The Sun Sidoarjo. Jurnal Bisnis Indonesia. Vol. 8 No. 1: 73-85.

8. Fatir, Rahmad Faz, Dahlan Fanani dan Inggang Perwangsa Nuralam. 2018. Pengaruh Experiential Marketing dan Emotional Branding Terhadap Kepuasan Konsumen (Studi pada Mahasiswa Malang Konsumen McDonald's Kota Malang).Jurnal Administrasi Bisnis. Volume 64 No. 2: 19-26.

9. Irawan, H. 2009. 10 Prinsip Kepuasan Pelanggan. Jakarta: Elex Media Komputindo.

10. Krishnan H.S \& Olshavsky, R.W. 1995. The Dual Role of Emotions in Consumer Satisfaction/ Dissatisfaction. Advances in Consumer Research.

11. Anoraga. 2002. Psikologi Kerja. Jakarta: Rineka Cipta.

12. Kotler, P. 2004. Marketing Management, Prentice-Hall International Editions, Englewood Cliffs, NJ.

13. Anwar, Mahfuzil, Grahita Chandrarin, Junianto Tjahjo Darsono dan Harianto Respati. 2017. Lecturer Job Performance Study: Motivation, Emotional Intelligence, Organizational Culture and Transformational Leadership as Antecedents with Job Satisfaction as an Intervening. Journal of Business and Management. Vol. 19, No, 6: 01-09 
14. Jasfar, Farida. 2005. Manajemen Jasa Pendekatan Terpadu, Cetakan Pertama. Jakarta: Penerbit Ghalia.

15. Sam, F., \& Tahir, M. 2010. Website quality and consumer online purchase intention of air ticket. Melaka 75300 Malaysia: Technology Management Department, Faculty of Technology Management \& Technopreneurship. University of Technical Malaysia Melaka.

16. Morgan, R., \& Hunt, S. 2008. The Commitment Trust Theory of Relationship Marketing. Journal of Marketing. Vol. 5 No. 3: 20-38.

17. Soegoto, A. 2013. Persepsi Nilai dan Kepercayaan terhadap Kepuasan dan Dampaknya terhadap Loyalitas Konsumen . Jurnal EMBA Vol. 1 No. 3, 1271-1283.

18. Tjiptono, Fandy. 2006. Pemasaran Jasa. Malang: Bayumedia.

19. Mayer, R., David, J., \& Schoorman, F. 2005. An Integratif Model of Organizational Trus . Academy of Management Review No. 30 No. 3, 709-734.

20. Wijanarka, Yuda, Sri Suryoko dan Widiartanto. 2014. Pengaruh Emotional branding dan Experiential marketing Terhadap Loyalitas Merek Eiger Adventure Melalui Brand trust dan Kepuasan Pelanggan Sebagai Variabel Intervening (Studi Kasus Pada Eiger Adventure Store Semarang). Diponegoro Journal of Social and Political of Science. Hal 1-12.

21. Leninkumar, Vithya. 2017. The Relationship between Customer Satisfaction and Customer Trust on Customer Loyalty. International Journal of Academic Research in Business and Social Sciences.Vol. 7 No. 4: 450-465. 